\title{
MACINTYRE, RAWLS AND CAVELL ON GAMES, RULES AND PRACTICES \\ UDC 17.032.2
}

\author{
Rastislav Dinić \\ University of Niš, Faculty of Philosophy, Department of Philosophy, Niš, Serbia
}

\begin{abstract}
John Rawls and Alasdair Macintyre are usually portrayed as opponents in the liberal-communitarian debate. However, Stanley Cavell's critique of Rawls' early paper "Two Concepts of Rules", helps us recognize a similarity between their accounts of rules, games and practices and the role that these play in moral life. This paper shows that both authors pay insufficient attention to personal relationships, the flexibility of our moral life, and the need to take responsibility for our moral positions. A scene from Thomas Hardy's "Jude the Obscure" is used to show how this presents a serious problem for Macintyre's model of tradition-based moral reasoning.
\end{abstract}

Key words: John Rawls, Stanley Cavell, Alasdair Macintyre, games, rules, practices, conversion.

\section{RAWLS AND CAVELL ON RULES, GAMES AND PRACTICES}

Rawls and Macintyre are presented in the standard Introductions to moral and political philosophy curriculum as representatives of two different approaches to ethics and politics, the approaches by now famous under the names of liberalism and communitarianism (Mulhall and Swift 1996). (I will disregard here for the purposes of brevity the contested nature of both of these labels, especially the latter one; for while Rawls explicitly recognizes his conception as liberal, Macintyre has repeatedly rejected the communitarian label) This fairly standard picture sees liberalism as standing for individualism and communitarianism, naturally, as standing for the claims of community.

Stanley Cavell's criticism of Rawls has, however, showed us that Rawls' picture is, paradoxically, not individualist enough, but as I intend to argue, it can also show us why Macintyre's conception is not communitarian enough. Both Rawls and Macintyre, however, fail in a very similar fashion - they underplay the flexibility of our moral life, and the importance of conversation and our existing attachments and commitments in assessing our moral position.

Received February 25, 2017 / Accepted June 19, 2017

Corresponding author: Rastislav Dinić

University of Niš, Faculty of Philosophy, Cirila i Metodija 2, 18000 Nišs, Serbia

E-mail: rastislav.dinic@filfak.ni.ac.rs 
I will start with briefly describing what is by now Cavell's fairly well known criticism of Rawls. In his book The Claim of Reason, Cavell devotes a whole chapter to Rawls' early paper "Two Concepts of Rules", in which Rawls defended rule utilitarianism against the accusations that it is incapable of accounting for ordinary moral intuitions about promising and punishing. Rawls' strategy was to point out the difference between two concepts of rules - summary rules and practice rules. Summary rules are simply "rule of thumb" directions to achieving the greatest utility in the long run, and there is no contradiction in breaking them in particular cases, on utilitarian grounds. It might be best in the long run if everyone stuck to the rule of never crossing the street on red light, instead of assessing the best course of action in each individual case of crossing the street, but when, for instance late at night, on a deserted street, I am running to fetch medicine for my sick friend, there is no reason for me not to cross on a red light, even if there is a summary rule which advises that I should not do so.

But then, Rawls says, we can also think of rules as practise rules - rules which define certain practices and social institutions (such as promising and punishing) - and these cannot be broken on utilitarian grounds, since the very concept of a practice forbids it:

"One realizes that what is required is the establishment of a practice, the specification of a new form of activity; and from this one sees that a practice necessarily involves the abdication of full liberty to act on utilitarian and prudential grounds. It is the mark of a practice that being taught how to engage in it involves being instructed in the rules which define it, and that appeal is made to those rules to correct the behavior of those engaged in it. Those engaged in a practice recognize the rules as defining it. The rules cannot be taken as simply describing how those engaged in the practice in fact behave: it is not simply that they act as if they were obeying the rules. Thus, it is essential to the notion of a practice that the rules are publicly known and understood as definitive; and it is essential also that the rules of a practice can be taught and can be acted upon to yield a coherent practice. On this conception', then, rules are not generalizations from the decisions of individuals applying the utilitarian principle directly and independently to recurrent particular cases. On the contrary, rules define a practice and are themselves the subject of the utilitarian principle (Rawls 1955, 24)".

Furthermore, Rawls defines practices as: “Any form of activity specified by a system of rules which defines offices, roles, moves, penalties, defenses and so on, and which gives the activity its structure. As examples one may think of games and rituals, trials and parliament" (Rawls 1955, 3).

Imagine someone, Rawls says, who would, in the middle of a game of baseball ask whether she could have four instead of three strikes: such a person would by asking this question show her incompetence in the game of baseball. Likewise, someone who would ask whether she could break a promise on utilitarian or prudential grounds would thereby show her incompetence in the "game" or practice of promising, which explicitly precludes the possibility of such a justification.

We can justify a whole practice on utilitarian grounds - there are, Rawls claims, clear utilitarian reasons for introducing the institution of promising - but we cannot justify particular acts in this practice on utilitarian grounds, for they are not even specifiable apart from this practice, or as Rawls puts it - rules are logically prior to particular actions. He writes: 
"One may illustrate this point from the game of baseball. Many of the actions one performs in a game of baseball one can do by oneself or with others whether there is the game or not. For example, one can throw a ball, run, or swing a peculiarly shaped piece of wood. But one cannot steal base, or strike out, or draw a walk, or make an error, or balk; although one can do certain things which appear to resemble these actions such as sliding into a bag, missing a grounder and so on. Striking out, stealing a base, balking, etc., are all actions which can only happen in a game. No matter what a person did, what he did would not be described as stealing a base or striking out or drawing a walk unless he could also be described as playing baseball, and for him to be doing this presupposes the rule-like practice which constitutes the game. The practice is logically prior to particular cases: un-less there is the practice the terms referring to actions specified by it lack a sense (Rawls 1955, 25)."

While Cavell applauds Rawls' overall account, he points out two main problems with it. First, according to Cavell, Rawls misrepresents moral life when he compares it to games. Unlike games, moral life does not have its rules set in advance. Second, Rawls to a certain extent misrepresents even the way games function as practices - as Cavell notes, if one could not competently ask whether she could have fours strikes, she could still competently ask many other questions, concerning what Cavell calls principles or advisory rules, questions which cannot be settled simply by citing the rules of the game. In a game of chess, one could ask whether, for instance it is the right thing to "develop your pieces as early as possible". Whether her challenge is competent or not would, in this case, have to be judged based on the reasons she could offer in its support, but this challenge could not be dealt with either by citing the defining rules of the game, since the challenge does not refer to them, or by citing the advisory rules, since they do not say what we must do in order to be seen as playing the game at all, but only what we ought to do in order to play it well. But about the latter question, reasonable disagreement may arise (Cavell 1979, 293-313).

What follows from these two points is that space for reasonable disagreement is much wider in moral life than in games - in games what we must do is clearly distinguished from what we ought to do. But there is no such clear distinction in moral life. Stephen Mulhall writes:

"Cavell's view, therefore, is that Rawls's understanding of games is as erroneous as his understanding of the phenomena he erroneously treats as analogous to games-namely, punishing and promising. But the most fateful implication of that erroneous analogy is its suggestion that how an action is to be described and evaluated in moral terms is determined in advance by something akin to a system of rules. Part of what will be called 'rules' in a game's rule book settle what counts as a move in the game, how disputes over whether or not a given action so counts are to be settled when certain eventualities arise, and what penalties or defences are open to those who make such a move. Without this prearranged common knowledge, games could not be practised, and umpires and referees could not do what they do. But moral conduct cannot be practised in this way, and moral conflict cannot be settled by reference to anything analogous to the defining rules of a practice. An action such as making a promise is not analogous to a move in a game, because in such contexts, what precisely was done-what 'move' was made, what 'defence' offered - is not settled in advance but is rather an open question (Mulhall 1997, 178)."

In moral life, therefore, we must make the distinction between what we must, and what we simply ought not to do, but in a particular case may still have good reason to. Therefore, moral life for Cavell is an arena, not only for playing well or badly within the given framework, but for self-definition - for taking up positions that we are prepared to take responsibility for. 
It is in this sense that Rawls' position is not individualist enough, for to quote Mulhall once more:

"Rawls ... restricts the potential individuality of our elaborations, and so our personal contribution to fixing that for which we are answerable, but he also restricts the capacity of world and mind to require such elaboration of us, to put in question any settled sense we might have of what we are or can be responsible for, and so of who we are. He transforms one person's determination of the limits of her vulnerability as an agent into an objective and foreseeable limitation upon human vulnerability as such, and thereby attenuates the self's sense of exposure to its world and to the opacity of its own motivations. In short, by restricting the self's capacity for self-definition, Rawls fortifies its capacity for selfpossession (Mulhall 1997, 180).”

But as Mulhall further notes, Rawls' approach also rigidifies our relationships with others. By making our moral relationships with others "purely a function of our success in applying the defining rules of our moral practices, and any discontinuation as the result of a certain kind of impersonal incompetence", he undercuts the possibilities for genuine moral encounters, and therefore - for intimacy. The Rawlsian self does not take responsibility for the rules it subjects itself to, and therefore denies the responsibility for any failure of a potential moral relationship. Once again, Mulhall sees the underlying motivation for such a move in the desire for self-possession - a self which relies on impersonal rules for defining interpersonal relationships makes itself much less vulnerable, but only at the price of making itself much less known:

"Such a vision rules out any advantages that might accrue from interpersonal relations of greater depth or intimacy, but it also rules out any disadvantages that might accrue from any deep or intimate claims that others may make upon us. For the key anxiety consequent upon remaining open to the development of a more personal relationship with others is that more of the self must be exposed in order to do so. Once again, Rawls sacrifices the self's potential for self-definition to its desire for self-possession (Mulhall 1997, 181)."1

\footnotetext{
${ }^{1}$ It was pointed out by an anonymous reviewer, that Cavell's criticism of Rawls' "Two Concepts of Rules" is aimed at a conception of institutional obligations, which Rawls' importantly modified in his later works, especially A Theory of Justice, and thus cannot be taken to apply to Rawls' theory in general. This is an apt and important remark, but unfortunately, a detailed answer would require a separate article. However, this much can be said here: according to Cavell's later critique of A Theory of Justice, formulated in his book Conditions Handsome and Unhandsome - Rawls' mature view of institutional obligations similarly closes off the space for a moral encounter (or as Cavell calls it, "conversation of justice"), albeit at a different place. Although in A Theory of Justice Rawls gives justice as fairness a crucial role in founding institutional obligations (a role completely absent from "Two Concepts of Rules") - he remains committed to resolving moral disagreements on the basis of rules, only in $A$ Theory of Justice, these are not any just any constitutive rules of a practice or an institution, but the famous principles of justice, which are a product of a hypothetical contract that guarantees that they would be accepted by free and equal individuals under the conditions of fairness. However, using these principles to resolve specific disagreements about the distance of our society from ideal justice, suffers from a similar problem as his conception from "Two Concepts of Rules", making our mutual relationships as citizens too contractual, and too rigidly defined. For a more detailed argument, see: Cavell 1990, Mulhall 1997, and Arviv 2010.
} 


\section{MACINTYRE ON GAMES, PRACTICES AND TRADITIONS}

There are many points in Cavell's criticism of Rawls which Macintyre might easily agree with, and I am primarily thinking of Cavell's claim that Rawls pictures moral relationships as too contractual, as well as with Cavell's assessment that this is typical for liberalism (Cavell 1979, 299). I suspect that he would also agree that the moral life Cavell talks about is in many respects unlike games, but I suspect he would also add that this applies primarily to modern moral life, but that there are visions of moral, or rather ethical life, which could be more aptly compared to games, for instance, the Aristotelian one:

"This portrayal of the rational agent as acting immediately and necessarily upon affirming his reasons for action is once again one very much at odds with our characteristically modern ways of envisaging a rational agent. Someone, we are inclined to say, may rehearse the good reasons which he or she has for taking a particular course of action and then at the very least may hesitate without at all ceasing to be rational. The thought may cross his or her mind that there may be some other good to be pursued or that the promptings of some desire should be listened to. Or the person may just not feel like acting in the way dictated by good reasons. Indeed this is why we are apt to suppose that between the evaluation of our reasons for action and action itself some further act of decision is necessary. No set of practical reasons, however compelling, need, on this dominant modern view be treated as conclusive.

What this shows of course is not that Aristotle was mistaken, but that he was describing a form of practical rational life both different from and in conflict with that at home in the social orders characteristic of modernity. But it may be instructive to consider those contemporary social contexts in which we do still find application for something very like Aristotelian conceptions of practical rationality. A hockey player in the closing seconds of a crucial game has an opportunity to pass to another member of his or her team better placed to score a needed goal. Necessarily, we may say, if he or she has perceived and judged the situation accurately, he or she must immediately pass. What is the force of this "necessarily" and this "must"?... We recognize the necessity and the immediacy of rational action by someone inhabiting a structured role in a context in which the goods of some systematic form of practice are unambiguously ordered. And in doing so we apply to one part of our social life a conception which Aristotle applies to rational life as such (MacIntyre 1988, 140)."

I will leave aside here the discussion of whether the Aristotelian view Macintyre is talking about here is really the one he himself endorses (or whether this view is the best interpretation of Aristotle's account). I believe that there are convincing arguments that he does, but I will not argue for that here, and instead simply take it for granted. ${ }^{2}$ Assuming this is so, what could be said of this account?

First, it could be said, with Cavell, that this account shares one of the problems that Cavell mentions with regards to the Rawlsian account - even if we take that the comparison with games is indeed in place when it comes to the Aristotelian vision, it still misrepresents games themselves, by erasing the distinction between defining and advisory rules, or between the ought and the must. According to Macintyre, it is only on pains of incompetence that one can forego to act in a certain way in a given situation.

But, as Peter Dula notes, a lot depends on the particular description Macintyre gives us of this situation: "It isn't just any hockey game but a crucial one. But most tellingly, it is not just any moment in the game but the closing seconds with the game on the line (Dula 2011, 54)." Setting the example this way significantly narrows the space for rational disagreement, but as

\footnotetext{
${ }^{2}$ For a different view, see Dula 2011, 53.
} 
every sports fan knows, even thus, it hardly eliminates this space. No matter how deep our agreement on strategies and principles of the game runs, there is still room for different assessments of the situation, and a variety of elaboratives and defenses open to one who, instead of passing the ball, decides to take a shot at the goal himself.

But even leaving that aside - what are we (we, today) to make of the Aristotelian account? Dealing with the hockey metaphor (which she calls "the most revealing in the book"), Martha Nussbaum (1989) concludes that "MacIntyre wishes to recover for the contemporary world the certainty of such an order; and clearly for him the promise of doing so is a great part of the appeal of "the universal Church," which he calls an "order in which each human being has his or her own allotted place and his or her own allotted duties."

While this may be so, it is important to note that Macintyre is very aware that we do not live in an Aristotelian polis and that contexts in which "the goods of some systematic form of practice are unambiguously ordered" are more of an exception than a rule. In order to answer the question of the importance of the Aristotelian account as Macintyre describes it for us today, we have to answer the question of how modern selves can come to inhabit such contexts.

It is in the very end of his book Which Justice? Whose Rationality? that Macintyre tries to answer the question of the significance of his inquiry for the modern reader, or as he says, "someone who, not as yet having given their allegiance to some coherent tradition of enquiry, is besieged by disputes over what is just and about how it is reasonable to act, both at the level of particular immediate issues... and at the level at which rival systematic tradition-informed conceptions contend" (Macintyre 1988, 394).

Macintyre claims that the way a modern reader should respond to the considerations that he brings to light will depend on the way she understands herself, and he goes on to list three typical versions of this self-understanding:

1. A type of person who is implicitly already committed to a tradition of moral enquiry and who will, in encountering this tradition's canonic texts, "often experience a shock of recognition: this is not only, so such a person may say, what I now take to be true but in some measure what I have always taken to be true" (Macintyre 1988, 394). For this type of person, then, initiation into a tradition of inquiry in which she already to a significant extent recognizes herself is relatively easy, and what is left to her is only to get to know this tradition better and join the current debates within it.

2. A type of person who sees all traditions of moral inquiry not only as alien to her, but as a kind of self-deception, that is, as expressions of arbitrary will which mask themselves as truth about morality. In order for a person of this type to be able to become a member of a tradition of inquiry, she would have to recognize herself as "as imprisoned by a set of beliefs which lack justification in precisely the same way and to the same extent as do the positions which they reject but also to understand themselves as hitherto deprived of what tradition affords, as persons in part constituted as what they are up to this point by an absence, by what is from the standpoint of traditions an impoverishment" (Macintyre 1988, 394). This change, however, would according to Macintyre have to be equal to conversion, for there are no purely rational ways in which she could acquire such insights, being that she is deprived of a tradition, and so of a basis for rationality in moral reasoning.

3. A type of person to whom most people in modern society belong to, who lives, as Macintyre puts it "betwixt and between" (Macintyre 1988, 394) the first two types, so between belonging to a specific tradition of moral inquiry, and some form of anomie, or detachment from all traditions. Such a person to a large extent accepts the moral discourse 
of liberal individualism, but in some domains of her life is still guided by certain fragments of different traditions. Since she is not completely detached from the rationality of traditions, although she does not identify with any of them completely, a path is open to her that is not open to persons of the second type: she can, as Macintyre writes, "dialectically test" (Macintyre 1988, 395) different traditions, their standards of rational justification, definitions of justice, lists of virtues, narratives of a good life, and on the basis of this she can achieve self-knowledge, that is, discover which of these traditions best describes her life so far, and which offers the most satisfactory answers to the moral dilemmas that she faces. Such an individual, Macintyre writes, "will be able to turn his or her own initial incoherences to argumentative advantage by requiring of each tradition that it supply an account of how these incoherences are best to be characterized, explained, and transcended... So such individuals will invite a tradition of enquiry to furnish them with a kind of self-knowledge which they have not as yet possessed by first providing them with an awareness of the specific character of their own incoherence and then accounting for the particular character of this incoherence by its metaphysical, moral, and political scheme of classification and explanation" (Macintyre 1988, 395).

Macintyre puts strong stress here on self-knowledge and self-understanding, but as I will show this is a kind a kind of a red herring, just like the appeals to dialectical reasoning, reasoned discussion between traditions, etc. They all lead us to believe that this process of picking and choosing traditions to join is more of a rationally deliberative process than it really is, or can be within Macintyre's framework. For in the end, there is no one else but the person in question that judges which tradition is a better fit for her and her life, which one gives a better account of her own experience. But could she be wrong? Could she make a false, or mistaken, or confused assessment of her own identity? And if she could, who could warn her of such a situation, or with regards to what criteria? After all the comparisons of traditions are done, and arguments dialectically confronted (incidentally, Macintyre certainly makes it seem as if everyone is a philosophy student with plenty of time on their hands to dialectically confront whole traditions of thought), it all boils down to the way one sees herself and her life, a sense of identification, $a$ shock of recognition. There are no, to use the Wittgensteinian phrase which seems appropriate outward criteria for the correctness of this recognition - and how could there be when there is, for the person in question, still no tradition within which such criteria can only exist.

It is in this sense that I claimed at the beginning that Macintyre's account turns out not to be communitarian enough. For this modern person living "betwixt and between" traditions, is, in Macintyre's description, not only completely deprived of all communal resources for rational deliberation, but also of all intimate ties and relationships: she has no friends, lovers, family, colleagues, whom she trusts, who know her intimately, and who can help her in her search for self-recognition and self-understanding. This person resembles no one so much as the Cartesian solitary thinker - she confronts arguments and histories of arguments, but she has to do it alone. She can only depend on the power of her own reason in coming to the right solution. The problem is that it is just this conception of rationality that Macintyre's whole book argues against. It is as if Macintyre is aware of this himself, when just a few lines after the quoted passages, toward the very end of the book, he writes: 
"A book which ends by concluding that what we can learn from its argument is where and how to begin may not seem to have achieved very much. Yet, after all, Descartes may have been right about one thing: in philosophy to know how to begin is the most difficult task of all. We, whoever we are, can only begin enquiry from the vantage point afforded by our relationship to some specific social and intellectual past through which we have affiliated ourselves to some particular tradition of enquiry, extending the history of that enquiry into the present: as Aristotelian, as Augustinian, as Thomist, as Humean, as post-Enlightenment liberal, or as something else" (Macintyre 1988, 401).

But this is not where we, as moderns, in Macintyre's own account, indeed begin. We begin by choosing where to begin, in which of the traditions he enumerates do we find ourselves. But that beginning must happen outside any traditions, in the very way, that is, in which Macintyre claims we cannot begin. The reference to Descartes is, I believe, not to be taken as an aside, but rather as an intimation that Descartes' problem of beginning still haunts Macintyre's account.

\section{CONVERSION, CONVERSATION AND RESPONSIBILITY}

Let me now point to an example which clearly shows what I see as a deficiency in Macintyre's account. It is from Thomas Hardy's famous novel, Jude the Obscure (Hardy 2002). The main character, Jude is a young working class man, but also an aspiring academic and intellectual. Although already married to a woman who left him and departed for Australia, he falls in love with his cousin Sue Brideshead, a free-spirited and intellectually inquisitive young woman who reads and quotes Mill, and mocks religious and social convention. She too will at one point get married, to a much older man, Richard Phillotson, but the marriage will prove to be a loveless one. She leaves her husband for Jude, and the two start living together, although out of wedlock. They will also have several children together while at the same time raising Jude's son from his first marriage. However, their non-traditional relationship, together with other obstacles to Jude's professional advancement, will keep them living in poor conditions. In the tragic crescendo of the book Jude's son from his first marriage, Little Father Time, kills his siblings and himself, after Jude had explained to him that they could not find lodging because "they were too many" (which is not true, the real reason lies in the fact that Jude and Sue are not married). The tragedy changes Sue, and she becomes religious, insisting that what Jude's son has done was a punishment for their living in sin, and that the only right thing to do is to return to their lawful spouses. Jude confronts her and the following exchange ensues:

“SUE: Don't criticize me, Jude-I can't bear it.-I have often told you so! You must take me as I am. I am a wretch - broken by my distractions! I couldn't bear it when Arabella came-I felt so utterly miserable I had to come away. She seems to be your wife still, and Richard to be my husband!

JUDE: But they are nothing to us!

SUE: Yes, dear friend, they are. I see marriage differently now! . . My babies have been taken from me to show me this! Arabella's child killing mine was a judgment; the right slaying the wrong. What, what shall I do! I am such a vile creature- too worthless to mix with ordinary human beings... But I have made up my mind that I am not your wife! I belong to him. I sacramentally joined myself to him for life. Nothing can alter it.

JUDE: But surely we are man and wife if ever two people were in this world? Nature's own marriage it is unquestionably! 
SUE: But not Heaven's. Another was made for me there, and ratified eternally in the church at Melchester.

JUDE: Sue, Sue - affliction has brought you to this unreasonable state! After converting me to your views on so many things, to find you suddenly turn to the right-about like this-for no reason whatever, confounding all you have formerly said through sentiment merely! You root out of me what little affection and reverence I had left in me for the church as an old acquaintance. ... What I can't understand in you is your extraordinary blindness now to your old logic. Is it peculiar to you, or is it common to Woman? Is a woman a thinking unit at all, or a fraction always wanting its integer? How you argued that marriage was only a clumsy contract - which it is - how you showed all the objections to it - all the absurdities. If two and two made four when we were happy together, surely they make four now? I can't understand it, I repeat!

SUE: Ah, dear Jude; that's because you are like a totally deaf man observing people listening to music. You say "What are they regarding? Nothing is there!" But something is. JUDE: That is a hard saying from you, and not a true parallel! You threw off old husks of prejudices, and taught me to do it; and now you go back upon yourself. I confess I am utterly stultified in my estimate of you.

SUE: Dear friend, my only friend, don't be hard with me. I can't help being as I am, I am convinced I am right - that I see the light at last. But $\mathrm{O}$, how to profit by it! ' $\mathrm{O}$ don't, don't, be so cruel to me, Jude, and I so unhappy! I can't bear it! I was in error - I cannot reason with you. I was wrong - proud in my own conceit. Arabella's coming was the finish. Don't satirize me: it cuts like a knife! (Hardy 2002, 339-340)."

What is this conversation about? It is, I would claim, primarily about two things - what is to be considered marriage (is the relationship between Sue and Jude - a marriage), and whether the change, or conversion that Sue has gone through represents a finding of her real self, or, on the contrary - a backsliding, a losing of way.

Jude makes two criticisms of Sue's decision - first that she is mistaken to see their marriage as a false marriage, or non-marriage, just as she is mistaken to see their respective marriages to their spouses to be true marriages. And second, that she is not herself, that she is, without good reason, giving up on her old beliefs and aspirations.

How does Sue answer these challenges? When it comes to marriage, she simply cites the rules of the institution of marriage to him - to be married is to be lawfully married in church. That is simply what marriage is. When it comes to her consistency, she has a different answer - she is aware that her beliefs have changed, but she sees her previous beliefs as an error (and more than that - a sin), and sees in them a cause of the suffering that she, and her loved ones had to endure.

What would Macintyre make of such a case? What could he? Regardless of which one of three types of modern persons we put her in, it is difficult to resist the conclusion that Sue is doing exactly what she is, in Macintyre's view, supposed to do - she is identifying herself with a tradition which enables her to understand her life narrative and her past errors, in the, as it seems to her, best possible way. But is she right? Is there anything to be said for Jude's questions? Could she be deluded now (or, as Jude puts it, "creed-drunk")? Could she be mistaken about the way she sees herself? About the real power of explanation the tradition offers her? I cannot see that Macintyre could add anything to Sue's answer to Jude - "I can't help being as I am, I am convinced I am right — that I see the light at last."

But is there anything wrong with this answer? I would argue that there is, and that once again Cavell could help us see what exactly goes wrong with it. In reading the conversation between Nora and Torvald, from Ibsen's Doll House, which is also a conversation about what makes a marriage, Cavell notes that Torvald's mistake is in believing that he is "above 
reproach" (the phrase Rawls used in A Theory of Justice) in his treatment of Nora, simply because Nora cannot point to specific rule that he has broken (Cavell 1990, 114). But, as Cavell notes:

"Certain promises are ones a community has stake in direct enough to legalize as contracts, e.g., ones concerning the exchange of money, rights of property, and marriage. Apart from the community's stake, you and I had an understanding - so I say; maybe you say to too, or deny it. No judge or rule knows better than we, and we have no rules that will decide. This is why there is a moral argument between us, why it has its forms. No explicit promise could have been more sacred than our understanding, or, given our supposed mutual trust, even appropriate (Cavell 1990, 114)."

While Sue quite obviously does not see herself as above reproach in many respects we might even say with Jude that she is reproaching herself too strongly about things she was not responsible for - there is one respect in which she does consider herself to be above reproach - and that is her very conversion, her new-found identification with a certain tradition and its rules. The problem is not that she has judged the way she did, but that she denies that she was the one who made judgment, that it was, in the end, her judgment about what a marriage is, and what her relationship to Jude is. She calls upon the rules of an institution to justify her judgment, thus, as Mulhall would put it, sacrificing her potential for self-definition to her desire for self-possession.

Recognizing this, we may see that this criticism applies to Macintyre too. For all the talk about self-knowledge, self-understanding and self-recognition, in the end he seems rather to opt for self-possession. This, however, as Mulhall aptly notes, and as Hardy vividly illustrates, "rules out any advantages that might accrue from interpersonal relations of greater depth or intimacy, but it also rules out any disadvantages that might accrue from any deep or intimate claims that others may make upon us." In simpler terms, it distorts our personal relationships, and makes intimacy impossible. It should not surprise us, then, that Macintyre's modern reader is, again in spite of all the talk about historical situatedness, presented as an isolated Cartesian self. All of her relationships, no matter how close and intimate, are presented as morally insignificant (or, as Sue sees her marriage to Jude - unreal) unless already situated in a context of more or less coherent tradition of practice. Mulhall's comment about Rawls therefore applies to Macintyre too: His "vision of the moral life effectively makes the self's commitments and relationships less fluid and more evident than they really are, and thereby conjures up a fantasy of a self that is more fixed, more invulnerable and more transparent to itself than it really is".

It is true that Macintyre tries to make as much space as he can for an exchange of reasons, therefore trying to make the act of conversion only the beginning, rather than an end of rational inquiry, but it is important to note that the only reasons and arguments exchanged are either between one's tradition of choice and other traditions, or within one tradition itself. There is no, nor could there be, an exchange of reasons between the person who converts to a tradition and someone outside this tradition, about the reasons for and against this conversion (or self-recognition). Much less is there, in the Macintyreian framework, possibility for taking responsibility for this conversion (for this conversion). The act which according to Macintyre stands at the beginning of moral inquiry might leave our everyday relationships in shambles. Perhaps that is a defensible position itself, but there is no space in Macintyre's account for asking about or offering any defenses for it. 


\section{CONCLUSION}

"I shun father and mother and wife and brother when my genius calls me. I would write on the lintels of the doorpost, Whim. I hope it is somewhat better than whim at last, but we cannot spend the day in explanation. Expect me not to show cause why I seek or why I exclude company (Emerson 1907)." Thus writes Emerson in Self-reliance. These lines point also to a severing of ties with the people closest to one, but, as Cavell aptly notes "where others will suggest this is a private appeal to faith, Emerson will suggest writing 'Whim' for all to see", and adds that Emerson cannot, "in his finitude, and his distrust of the exchanges of words as they now stand in society, claim more than the existence of his own call to write otherwise. Whether it is more, whether it speaks for the world and to others, is not for him to say" (Cavell 2004, 30-31). This is the problem of beginnings in the conditions of modernity - no "judge or rule", tradition, practice, or institution, can help us in our search for self-knowledge, we have to achieve it ourselves by finding a position that we are prepared to take responsibility for. It seems that the task that lies in front of Macintyre, or whoever takes it upon herself to develop his account further, is one of developing a more elaborate account of conversion (or, as Emerson /1907/ would say, aversion). One which would be more attentive to conversations and moral encounters, not just between traditions, but between persons.

\section{REFERENCES}

Arviv, Nadav. “Autonomy Here and Now: Cavell's Criticisms of Rawls”. European Journal of Pragmatism and American Philosophy 2 (2010): 186-210.

Cavell, Stanley. Cities of Words: Pedagogical Letters on a Register of the Moral Life. Cambridge, Massachusetts: Belknap Press of Harvard University Press, 2004.

Cavell, Stanley. Conditions Handsome and Unhandsome. Chicago and London: UC Press, 1990.

Cavell, Stanley. The Claim of Reason. New York: Oxford University Press, 1979.

Dula, Peter. Cavell, Companionship, and Christian Theology. Oxford: Oxford University Press, 2011.

Emerson, Ralph Waldo. "Self-Reliance”. In Essays, edited by Edna H. L. Turpin. New York: Charles E. Merrill Co., 1907. Available at: http://www.gutenberg.org/files/16643/16643-h/16643-h.htm_(accessed February 3. 2017).

Hardy, Thomas. Jude the Obscure. Oxford and New York: Oxford University Press, 2002.

MacIntyre, Alasdair. Whose Justice? Which Rationality? Notre Dame: University of Notre Dame Press, 1988.

Mulhall, Stephen, and Adam Swift. Liberals and Communitarians. Oxford: Wiley-Blackwell, 1996.

Mulhall, Stephen. „Promising, Consent, and Citizenship: Rawls and Cavell on Morality and Politics”. Political Theory 25 (1997): 171-192.

Nussbaum, Martha. "Recoiling From Reason" (review of Whose Justice? Which Rationality? by Alasdair Macintyre, The New York Review of Books), December 7, 1989. http://www.nybooks.com/articles/1989/12/07/recoiling-fromreason/

Rawls, John. "Two Concepts of Rules”. The Philosophical Review 64 (1955): 3-32. 


\section{MEKINTAJER, ROLS I KAVEL O IGRAMA, PRAVILIMA I PRAKSAMA}

Džon Rols i Alasder Mekintajer se obično smatraju filozofskim oponentima, koji se nalaze na suprotnim stranama u debati liberala i komunitarista. Međutim, Rolsovog ranog rada „Dva pojma pravila", pomaže nam da uočimo sličnost između njihovih modela pravila, igara i praksi i uloga koje ove igraju u moralnom životu. Ovaj rad pokazuje da oba autora ukazuju nedovoljnu pažnju ličnim odnosima, fleksibilnosti našeg moralnog života i potrebi da preuzmemo odgovornost za svoje moralne pozicije. Scena iz romana Tomasa Hardija, ,,Neznani Džud“"koristi se kao primer kako bi se pokazalo da ovo predstavlja ozbiljan problem za Mekintajerov model moralne racionalnosti zasnovane na tradiciji.

Ključne reči: Džon Rols, Stenli Kavel, Alasder Mekintajer, igre, pravila, prakse, preobraćenje. 